\title{
FUNGI COLONIZING THE SOIL AND ROOTS OF TOMATO (Lycopersicum esculentum Mill.) PLANTS TREATED WITH BIOLOGICAL CONTROL AGENTS
}

\author{
${ }^{1}$ Bożena Cwalina-Ambroziak, ${ }^{2}$ Maciej K. Nowak \\ 'Department of Phytopathology and Entomology, University of Warmia and Mazury, \\ 10-720 Olsztyn, Prawocheńskiego 17, Poland e-mail: bambr@uwm.edu.pl \\ ${ }^{2}$ Tymbark SA, Department in Olsztynek, 11-015 Olsztynek, Zielona 16, Poland
}

Received: 18.04.2011

\section{Abstract}

Tomato plants, cv. Rumba Ożarowska, grown in the greenhouse of the University of Warmia and Mazury, were protected in the form of alternate spraying (twice) and watering (twice) with $5 \%$ aqueous extracts of the following plant species: Aloe vulgaris Lam., Achillea millefolium L., Mentha piperita L., Polygonum aviculare L., Equisetum arvense L., Juglans regia L. and Urtica dioica L. Plants not treated with the extracts served as control. After fruit harvest, samples of roots and soil were collected. The roots were disinfected and next placed on PDA medium. Soil-colonizing fungi were cultured on Martin medium. Fungi were identified microscopically after incubation.

Pathogenic fungal species, Colletotrichum coccodes, Fusarium equiseti, F. oxysporum and F. poae, accounted for over $60 \%$ of all isolates obtained from the roots of tomato plants. The soil fungal community was dominated by yeast-like fungi $(75.4 \%)$, whereas pathogenic fungi were present in low numbers. The applied 5\% aqueous plant extracts effectively reduced the abundance of fungi, including pathogenic species, colonizing tomato plants and soil. The extract from $P$. aviculare showed the highest efficacy, while the extract from J. regia was least effective. Fungi showing antagonistic activity against pathogens (Paecilomyces roseum and species of the genus Trichoderma) were isolated in greatest abundance from the soil and the roots of tomato plants treated with A. millefolium, M. piperita and $U$. dioica extracts.

Key words: pathogenic fungi, saprotrophic fungi, roots of tomato plants, soil

\section{INTRODUCTION}

Plants extracts show potential for biocontrol of the following pathogenic species: Colletotrichum capsici (O bag w u et al. 1997), Rhizoctonia solani (Srivastova and Lal, 1997; Sehajpal et al.
2009), Phytophthora infestans (Schmitt et. al. 2005), Erwinia carotovora ssp. carotovora (B d l i y a and D a h i r u , 2006), Fusarium oxysporum f. sp. ciceris (S a h a y a r a et al. 2006) and Verticillium dahliae (S h o houg et al. 2009). In a pot experiment carried out by B u rg i e 1 et al. (2008), extracts from plants of the family Apiaceae provided effective control of powdery mildew Erysiphe spp. on marigolds Calendula officinalis. Slusare nko et al. (2008) and Portz et al. (2008) demonstrated that greenhouse vegetables may be protected against fungus-like organisms (e.g. Phytophthora and Pseudoperonospora) with allicin from Allium sativum. Extracts from Paeonia suffruticosa, Hedera helix (R o h n e r et al. 2004), plants of the genus Cameroon (G o u fo et al. 2008) and A. sativum (Portz et al. 2008) showed high efficacy in late blight control in tomatoes. According to Konstantinidou-Doltsinis et al. (2006), Reynoutria sachalinensis extract has a fungistatic effect on Leveillula taurica, the causal agent of powdery mildew of tomatoes.

The aim of this study was to determine the quantitative and qualitative composition of fungal communities colonizing the soil and roots of tomato plants treated with aqueous plant extracts.

\section{MATERIALS AND METHODS}

Tomato plants Lycopersicum esculentum Mill., cv. Rumba Ożarowska, were grown in the greenhouse of the University of Warmia and Mazury in Olsztyn in 2006-2007. Tomato seedlings were planted in pots (one seedling per pot) filled with peat substrate and garden soil at a ratio of 1:3 (total $9 \mathrm{dm}^{3}$ of substrate, without inoculum). The experiment involved biological control 
(three weeks after seedling planting) in the form of alternate spraying (twice) and watering (twice) at 10-day intervals with aqueous extracts of the following plant species: Aloe vulgaris Lam., Achillea millefolium L., Mentha piperita L., Polygonum aviculare L., Equisetum arvense L., Juglans regia L. and Urtica dioica L. (45 ml/plant). Aqueous extracts were prepared from dry plant material $(50 \mathrm{~g})$ mixed with water $(1 \mathrm{l})$, except for aloe whose fresh leaves were crushed in a mortar to obtain 5\% extract. The experiment was performed in six replications (six pots). Plants not treated with the extracts served as control. After fruit harvest, samples of roots and soil were collected from each pot. Following disinfection (with $50 \%$ ethanol and $1 \%$ sodium hypochlorite), pieces $(0.5 \mathrm{~cm})$ were cut from the roots and placed on PDA medium (in 5 replications per treatment -5 Petri dishes $x 6$ pieces of roots). Soil samples collected from under each plant (at a depth of up to $5 \mathrm{~cm}$ ) were placed in dishes and mixed with a rotary motion. $149 \mathrm{~g}$ fine sand was mixed thoroughly with $1 \mathrm{~g}$ of the resultant fraction in a flask with a rotary motion (for 10 minutes). $300 \mathrm{~mm}^{3}$ of the mixture was poured with Martin medium $\left(50^{\circ} \mathrm{C}\right)$ (M a ń k a , 1974). Colonies of yeast-like fungi were counted. After 5 days of incubation at $22^{\circ} \mathrm{C}$, fungal colonies were transferred to PDA slants for species identification (B o o th , 1971; Ellis, 1971; Skirgiełło et al. 1979).

\section{RESULTS AND DISCUSSION}

The fungal soil community was more abundant and diverse than the community colonizing the roots of tomato plants. The applied biological control, which involved alternate spraying and watering with aqueous extracts of seven plant species, effectively reduced the

abundance of fungi, including pathogenic species, colonizing tomato plants and soil. Fifteen species of filamentous fungi were isolated from the tomato roots (Table 1). Yeast-like fungi accounted for $6.4 \%$ of all isolates (Fig. 1a). Among saprotrophic fungi, species of the order Mucorales were isolated in relatively high numbers (Mortierella alpina, M. isabelina, M. zonata and Rhizopus nigricans - over $14 \%$ of all isolates). Fungi showing antagonistic activity against pathogens were represented by $P$. roseum, Trichoderma hamatum and T. harzianum. They were isolated in greatest abundance from the roots of tomato plants treated with A. millefolium, $M$. piperita, E. arvense and U. dioica extracts (Fig. 1b).

In a study by Jamiołkowska and Wag n e r (2007), the essential oil from Thymus vulgaris, containing thymol and carvacrol, increased the abundance of fungi of the genera Trichoderma and Mucor on the roots of pepper plants, but it also inhibited the growth of Alternaria alternata and $F$. oxysporum on the aboveground parts of plants. According to
O s o r i o et al. (2009), the development of pathogens such as A. alternata, $C$. coccodes, $F$. oxysporum, $F$. sambucinum, $F$. solani and $R$. solani may be inhibited by phenolic extracts from Carya illineonsis, Punica granatum and Larrea tridentate.

The abundance of pathogenic fungi isolated from the roots of tomato plants ranged from $32 \%$ in the treatment with $P$. aviculare extract (a significantly lower number of pathogens was isolated from the tomato roots in this treatment, compared with other treatments - Table 3) to $72 \%$ in the control treatment and in the treatment with $J$. regia extract. In all treatments, the predominant species was $C$. coccodes - the only pathogen that colonized the roots of tomato plants treated with A. vulgaris, M. piperita, $P$. aviculare and $J$. regia extracts. Fungi of the genus Fusarium were isolated in highest numbers from the roots of control tomato plants (34.5\%). Those pathogens are the causal agents of tomato root rot (B y rne et al. 1997; V a t $\mathrm{che}$ and $\mathrm{Hadj}$ idimitrov, 2006). In an in vitro experiment, B u r g i e ł et al. (2008) noted an inhibitory effect of extracts from plants of the family Apiaceae on the growth of A. alternata, Botrytis cinerea and Fusarium culmorum. As demonstrated by $\mathrm{S}$ e fidk on et al. (2004), extract from the seeds of Heracleum sosnowskyi was characterized by the highest activity against F. culmorum, due to high concentrations of esters found also in other species of this genus. In an earlier study, W ols k i et al. (1996) attributed the fungistatic effects of $H$. sosnowskyi extracts to the production of secondary metabolites such as coumarins and furanocoumarins.

The soil fungal community was dominated by yeast-like fungi, which accounted for $75.4 \%$ of all isolates from all treatments (Fig. 2a). Among 27 species of filamentous fungi (Table 2), members of the genus Penicillium were found in relatively large numbers, in particular in treatments with J. regia and $U$. dioica extracts (approximately 18\% of all isolates in each treatment). Fungi of the order Mucorales (M. alpina, M. isabelina, M. vinacea, Mucor hiemalis and R. nigricans) and antagonists of plant pathogens ( $P$. roseum, T. hamatum, T. harzianum, T. koningii, T. polysporum and $T$. viride had a $3.9 \%$ and $4.5 \%$ share of all isolates, respectively. The latter were most frequently isolated from soil samples collected from under tomato plants sprayed with A. millefolium, M. piperita and U. dioica extracts (Fig. 2b).

Pathogenic fungal species, including $B$. cinerea, $C$. coccodes, $F$. oxysporum and $F$. solani, were seldom isolated from the soil. They were not found in treatments with $P$. aviculare and $E$. arvense extracts. According to $\mathrm{S}$ a s - Piotrowska and Pi otrows k i (1995, 2003), the fungicidal properties of extracts from plants of the family Polygonaceae against Fusarium species result from high concentrations of phenolic acids. 
Table 1

Fungi isolated from the roots of tomato plants during the investigation period ( $\%$ of all isolates)

\begin{tabular}{|c|c|c|c|c|c|c|c|c|}
\hline Species & $\mathrm{C}$ & Av & Am & $\mathrm{Mp}$ & $\mathrm{Pa}$ & $\mathrm{Ea}$ & $\mathrm{Jr}$ & Ud \\
\hline Aureobasidium pullulans (de Bary) Arnaud & & & & & & 12.5 & & \\
\hline Cladosporium cladosporioides (Fres.) de Vries & & & & & & 12.5 & & \\
\hline Colletotrichum coccodes (Wallr.) Hughes* & 37.9 & 58.3 & 38.5 & 65.3 & 31.6 & 45.8 & 71.4 & 44.0 \\
\hline Fusarium equiseti (Corda) Sacc. * & 6.9 & & 11.5 & & & 4.2 & & 8.0 \\
\hline Fusarium oxysporum Schlecht.* & 13.8 & & & & & 12.5 & & 12.0 \\
\hline Fusarium poae (Peck.) Wollenweber* & 13.8 & & 3.8 & & & & & \\
\hline Mortierella alpina Peyronel & & & 7.8 & 8.7 & 15.8 & & 4.8 & 8.0 \\
\hline Mortierella isabelina Oudemans & & 10.4 & 3.8 & & 10.5 & & 4.8 & \\
\hline Mortierella zonata Linn. ex Gams & & & 3.8 & 4.3 & 15.8 & & & \\
\hline Paecilomyces roseum (Thom) Samson** & & & & & & 8.3 & & \\
\hline Penicillium spp. & & 6.3 & & & 5.3 & & & 8.0 \\
\hline Rhizopus nigricans Ehrenberg & & & 11.5 & & 10.5 & 4.2 & & \\
\hline Sporotrichum olivaceum (Link) Fries & 10.4 & 10.4 & 11.5 & 4.3 & & & 9.5 & 8.0 \\
\hline Trichoderma hamatum (Bon.) Bain** & 3.4 & & 7.8 & & & & & \\
\hline Trichoderma harzianum Rifai** & 3.4 & 4.2 & & 8.7 & & & & 8.0 \\
\hline Yeast-like & 10.4 & 10.4 & & 8.7 & 10.5 & & 9.5 & 4.0 \\
\hline Total number of isolates & 58 & 48 & 52 & 46 & 38 & 48 & 42 & 50 \\
\hline
\end{tabular}

Explanations: C - control, Av - Aloe vulgaris Lam., Am - Achillea millefolium L., Mp - Mentha piperita L., Pa - Polygonum aviculare L., Ea - Equisetum arvense L., Jr - Juglans regia L. i Ud - Urtica dioica L. * - pathogenic fungi, ** - antagonistic fungi

Table 2

Fungi isolated from soil samples collected from under tomato plants during the investigation period (\% of all isolates)

\begin{tabular}{|c|c|c|c|c|c|c|c|c|}
\hline Fungi & $\mathrm{C}$ & Av & Am & $\mathrm{Mp}$ & $\mathrm{Pa}$ & $\mathrm{Ea}$ & $\mathrm{Jr}$ & $\mathrm{Ud}$ \\
\hline Aureobasidium pullulans (de Bary) Arnaud & & 1.1 & & 1.0 & 1.1 & & & \\
\hline Botrytis cinerea Pers.* & 0.7 & & & & & & & \\
\hline Cladosporium cladosporioides (Fres.) de Vries & 1.4 & 1.1 & & & & & & \\
\hline Colletotrichum coccodes (Wallr.) Hughes* & & & & 1.0 & & & & \\
\hline Fusarium equiseti (Corda) Sacc. * & 1.4 & & & & & & & \\
\hline Fusarium oxysporum Schlecht.* & 1.4 & 1.1 & & & & & & 1.0 \\
\hline Fusarium solani (Mart.) Sacc.* & & & 1.0 & & & & 3.2 & \\
\hline Gilmaniella humicola Barron & 0.7 & & & & & & & \\
\hline Gliomastix murorum (Corda) Hughes & 2.1 & & & 7.0 & 1.1 & 1.3 & & 1.0 \\
\hline Humicola fuscoatra Traaen & & & & & & 1.3 & & \\
\hline Humicola grisea Traaen & & & 1.0 & & 1.1 & 1.3 & 4.3 & \\
\hline Humicola nigrescens Omvik & 2.7 & 1.1 & & 1.0 & & 1.3 & & 1.0 \\
\hline Mortierella alpina Peyronel & 1.4 & & & 1.0 & & 1.3 & 1.1 & 3.8 \\
\hline Mortierella isabelina Oudemans & & 1.1 & 1.0 & & 1.1 & & & 1.0 \\
\hline Mortierella vinacea Dixon-Stewart & & & & & 1.1 & & & \\
\hline Mucor hiemalis Wehmer & & & & & & & 1.1 & 3.8 \\
\hline Paecilomyces roseum (Thom) Samson** & & & 1.0 & 5.0 & & & & 1.0 \\
\hline Papulaspora irregularis Hotson & 2.7 & & & & & 1.3 & & \\
\hline Penicillium spp. & 6.2 & 1.1 & 3.0 & 3.0 & 11.2 & 6.3 & 17.2 & 18.3 \\
\hline Periconia macrospinosa Lefebvre and Johnson & 1.4 & & 1.0 & & & & 4.3 & \\
\hline Rhizopus nigricans Ehrenberg & 0.7 & 3.4 & & 2.0 & & 2.5 & 4.3 & \\
\hline Sporotrichum olivaceum Fries & 2.1 & & & 1.0 & & & & \\
\hline Trichoderma hamatum (Bon.) Bain** & & & 1.0 & 1.0 & & & & 4.8 \\
\hline Trichoderma harzianum Rifai** & & 3.4 & 3.9 & & 1.1 & 3.8 & & 1.0 \\
\hline Trichoderma koningii Oudemans** & & & & 1.0 & & & 2.2 & \\
\hline Trichoderma polyversum (Link ex Pers.) Rifai** & & & 1.0 & 1.0 & & & & \\
\hline Trichoderma viride Person ex Tries.** & & & 2.9 & & 1.1 & & & \\
\hline Yeast-like & 75.1 & 85.5 & 82.2 & 73.0 & 81.1 & 79.6 & 62.3 & 63.3 \\
\hline Non-sporulating fungi & & 1.1 & 1.0 & 2.0 & & & & \\
\hline Total number of isolates & 292 & 176 & 206 & 198 & 178 & 160 & 186 & 208 \\
\hline
\end{tabular}

Explanations as in Table 1 
Table 3

Fungi isolated most frequently from tomato organs and soil (mean number of isolates in years)

\begin{tabular}{cccccccccccc}
\hline Treatments & \multicolumn{3}{c}{ Roots } & \multicolumn{7}{c}{ Soil } \\
\hline & Path & Antag & Muc & Spor & Yeast & Path & Antag & Muc & Pen & Yeast \\
\cline { 2 - 11 } Control & $21.0 \mathrm{a}^{*}$ & $2.0 \mathrm{a}$ & $0 \mathrm{c}$ & $3.0 \mathrm{a}$ & $3.0 \mathrm{a}$ & $5.0 \mathrm{a}$ & $0 \mathrm{~d}$ & $3.0 \mathrm{~b}$ & $9.0 \mathrm{ab}$ & $110.0 \mathrm{a}$ \\
$\mathrm{Av}$ & $14.0 \mathrm{ab}$ & $1.0 \mathrm{a}$ & $2.5 \mathrm{c}$ & $2.5 \mathrm{a}$ & $2.5 \mathrm{a}$ & $1.0 \mathrm{ab}$ & $3.0 \mathrm{bcd}$ & $4.0 \mathrm{ab}$ & $1.0 \mathrm{~b}$ & $75.0 \mathrm{a}$ \\
$\mathrm{Am}$ & $14.0 \mathrm{ab}$ & $2.0 \mathrm{a}$ & $7.0 \mathrm{ab}$ & $3.0 \mathrm{a}$ & $0 \mathrm{a}$ & $1.0 \mathrm{ab}$ & $10.0 \mathrm{a}$ & $1.0 \mathrm{~b}$ & $3.0 \mathrm{~b}$ & $85.0 \mathrm{a}$ \\
$\mathrm{Mp}$ & $15.0 \mathrm{ab}$ & $2.0 \mathrm{a}$ & $3.0 \mathrm{bc}$ & $1.0 \mathrm{a}$ & $2.0 \mathrm{a}$ & $1.0 \mathrm{ab}$ & $8.0 \mathrm{ab}$ & $3.0 \mathrm{~b}$ & $3.0 \mathrm{~b}$ & $72.0 \mathrm{a}$ \\
$\mathrm{Pa}$ & $6.0 \mathrm{~b}$ & $0 \mathrm{a}$ & $10.0 \mathrm{a}$ & $0 \mathrm{a}$ & $2.0 \mathrm{a}$ & $0 \mathrm{~b}$ & $2.0 \mathrm{~cd}$ & $2.0 \mathrm{~b}$ & $10.0 \mathrm{ab}$ & $72.0 \mathrm{a}$ \\
$\mathrm{Ea}$ & $15.0 \mathrm{ab}$ & $2.0 \mathrm{a}$ & $1.0 \mathrm{c}$ & $0 \mathrm{a}$ & $0 \mathrm{a}$ & $0 \mathrm{~b}$ & $3.0 \mathrm{bcd}$ & $3.0 \mathrm{~b}$ & $5.0 \mathrm{~b}$ & $64.0 \mathrm{a}$ \\
$\mathrm{Jr}$ & $15.0 \mathrm{ab}$ & $0 \mathrm{a}$ & $2.0 \mathrm{c}$ & $2.0 \mathrm{a}$ & $2.0 \mathrm{a}$ & $3.0 \mathrm{ab}$ & $2.0 \mathrm{~cd}$ & $6.0 \mathrm{ab}$ & $16.0 \mathrm{a}$ & $58.0 \mathrm{a}$ \\
$\mathrm{Ud}$ & $16.0 \mathrm{a}$ & $2.0 \mathrm{a}$ & $2.0 \mathrm{c}$ & $2.0 \mathrm{a}$ & $1.0 \mathrm{a}$ & $1.0 \mathrm{ab}$ & $7.0 \mathrm{abc}$ & $9.0 \mathrm{a}$ & $19.0 \mathrm{a}$ & $66.0 \mathrm{a}$ \\
\hline
\end{tabular}

Explanations as in Table 1, Path - pathogens, Antag - antagonists, Muc - Mucorales, Spor - Sporotrichum olivaceum, Yeast yeast-like, Pen - Penicillium spp.

* means with the same letter do not differ significantly (Duncan's test, $\mathrm{p}=0.01$ )

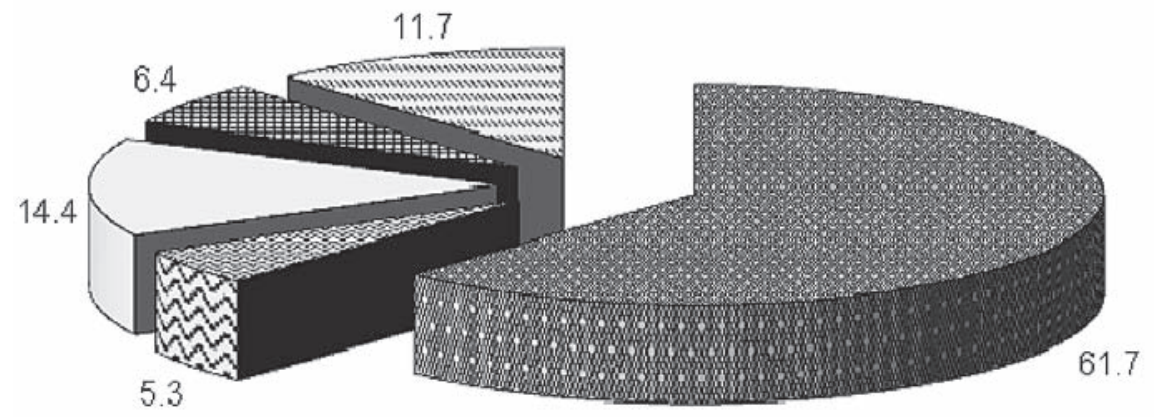

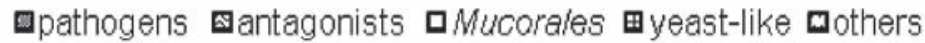

a. fungi isolated most frequently

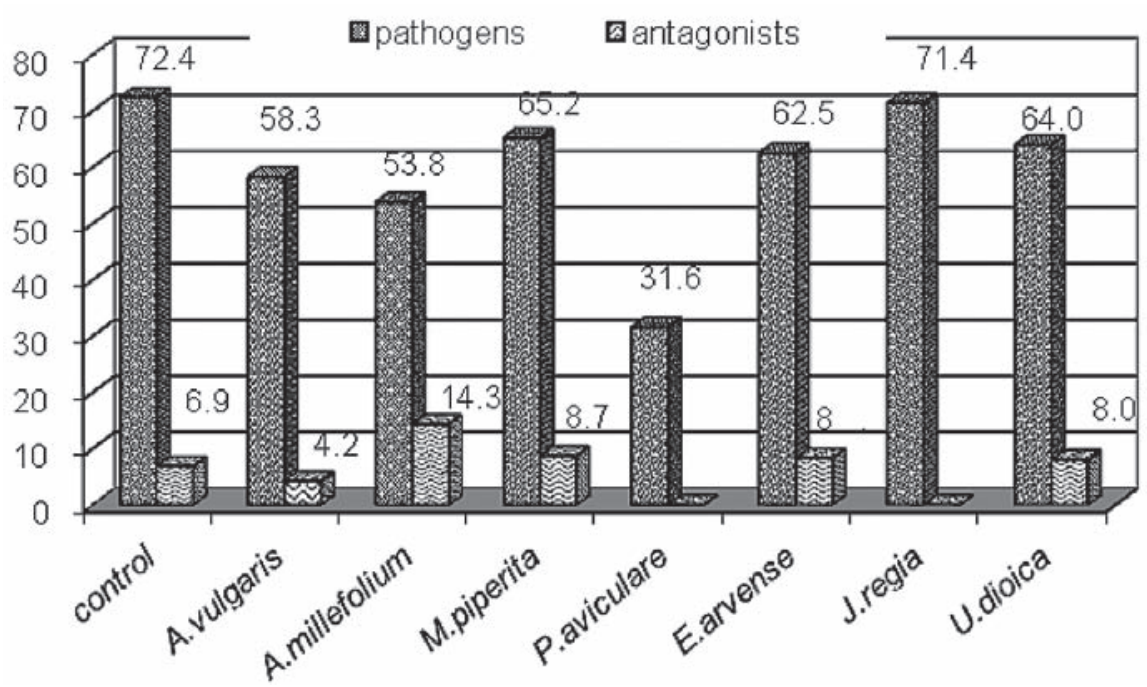

b. pathogenic and antagonistic fungi isolated in individual treatments

Fig. 1. Fungi isolated from the roots of tomato plants during the investigation period (\%) 


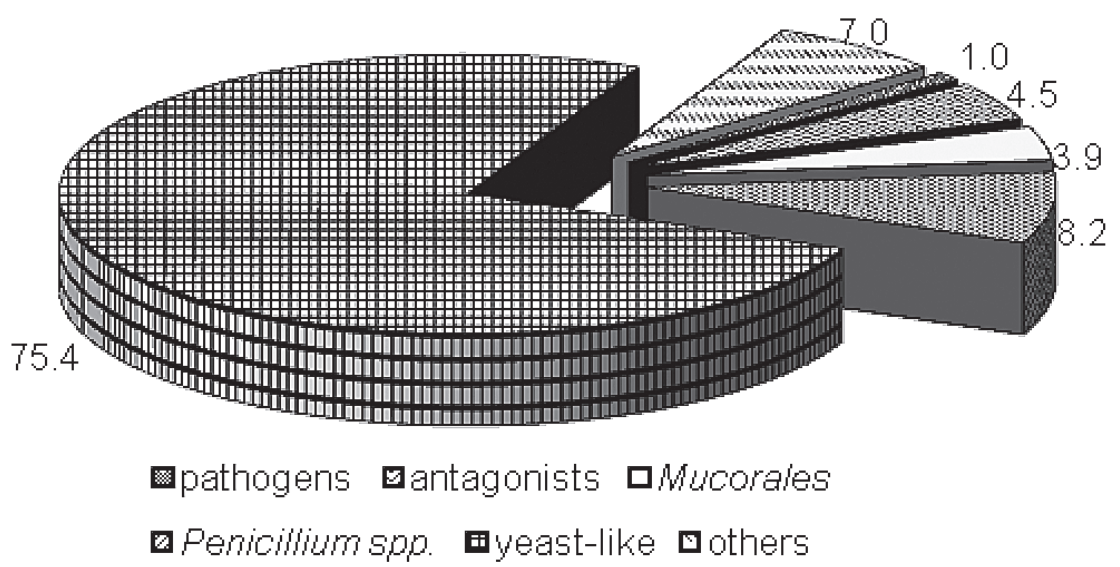

a. fungi isolated most frequently

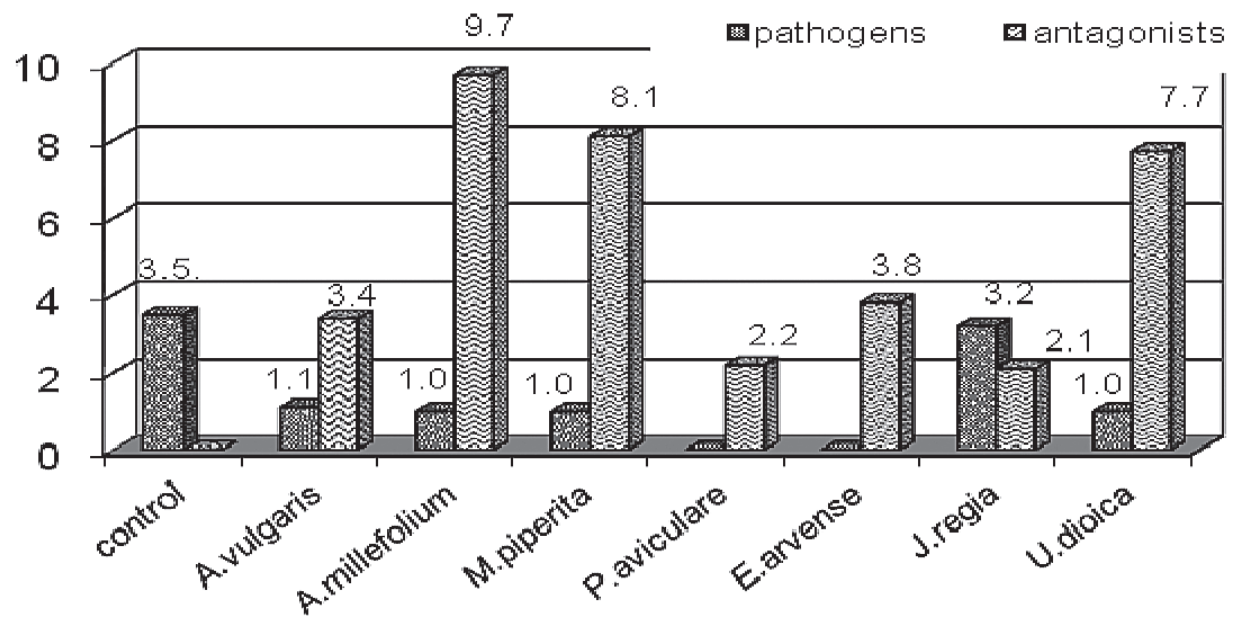

b. pathogenic and antagonistic fungi isolated in individual treatments

Fig. 2. Fungi isolated from soil during the investigation period (\%)

\section{CONCLUSIONS}

The applied biological control, which involved alternate spraying and watering with aqueous extracts of seven plant species, effectively reduced the abundance of fungi, including pathogenic species, colonizing tomato plants and soil.

The extract from Polygonum aviculare showed the highest efficacy.

C. coccodes and Fusarium spp. were isolated in great abundance (over 70\%) from the roots of control tomato plants and tomato plants treated with an aqueous extract from Juglans regia.

The soil fungal community was dominated by yeast-like fungi, whereas pathogenic fungi were present in low numbers.

\section{REFERENCES}

Bdliya B.S., Dahiru B., 2006. Efficacy of some plant extracts on the control of potato tubers soft rot caused by Erwinia carotovora ssp. carotovora. J. Plant Prot. Res. 46 (3): 285-294.

B ooth T.C., 1971. The genus Fusarium. Commonwealth Mycological Institute Kew Surrey, England.

Burgieł Z.J., Tomaszkiewicz-Potępa A., Vogt O., Burgieł M.M., 2008. Fungistatyczne własności ekstraktów z nasion wybranych roślin należących do rodziny Apiaceae./ Fungistatic properties of extracts from seeds of selected species of apiaceaeaus plants. Progr. Plant Protection/ Post. Ochr. Roślin, 48 (2): 701 705. (in Polish).

Byrne J.M., Hausbeck M.K., Hammerschmidt R., 1997. Conidial germination and appressorium formation of Colletotrichum coccodes on tomato foliage. Pl. Dis. 81: 715-718.

E11 is M. B., 1971. Dematiaceus hyphomycetes. Commonwealth Mycological Institute Kew Surrey, England.

Jamiołkowska A., Wagner A., 2007. Próby zastosowania olejku tymiankowego do ochrony papryki uprawianej w polu przed grzybami chorobotwórczymi. /Effect of thyme oil in protection against fungal diseases on 
field-grown pepper. Prog. Plant Protection/ Post. Ochr. Roślin, 47 (4): 149-153. (in Polish).

Konstantinidou-Doltsinis S., Markellou E., Fanouraki M.N., Kasselaki A.M., Koumaki C.M., Schmitt A., 2006 . Efficacy of Milsana Ò, a formulated plant extract from Reynoutria sachalinensis, against powdery mildew of tomato ( $\mathrm{Lev}$ eillula taurica) (Lév.) Arn. Biocontr. 51: 375-392.

Mańka K ., 1974. Zbiorowiska grzybów jako kryterium oceny wpływu środowiska na choroby roślin./ Fungal communities as a criterion for estimating the effect of the environment on plant diseases. Zesz. Probl. Post. Nauk Rol. 160: 9-23. (in Polish)

Obagwu J., Emechebe A.M., Adeoti A.A., 1997. Effects of extracts of garlic (Allium sativum) bulb and neem (Azadirachta indica) seed on the mycelia growth and sporulation of Colletotrichum capsici. J. Agric. Technology, 5: 51-55.

Osorio E., Flores M., Hernandez D., Ventura J., Rodriguez R., 2009. Biological efficiency of polyphenolic extracts from pecan nuts shell (Carya illinoensis), pomegranate husk (Punica granatum) and creosote bush leaves (Larrea tridentata Cov.) against plant pathogenic fungi. Ind. Crops Prod. 31:153-157.

Portz D., Koch E., Slusarenko A.J., 2008. Effects of garlic (Allium sativum) juice containing allicin on Phytophthora infestans and downy mildew of cucumber caused by Pseudoperonospora cubensis Eur. J Pl. Pathology, 122:197-206.

Sahayaraj K., Namasivayam S.K.R., Borgio J . A . F., 2006. Influence of three plant extracts on $\mathrm{Fu}$ sarium oxysporum $\mathrm{sp}$. ciceris mycelium growth. J. Pl. Prot. Res. 46 (4): 335-338.

Sas-Piotrowska B., Piotrowski W., 1995. Activity of extract from Polygonaceae plants toward Fusarium species. VI Conf. of the Polish Phytopathol. Society, Skierniewice, "Biological Control of Soil-Borne and PostHarvest Pathogens", 18-19 kwietnia 1995",149-153.

Sas-Piotrowska B., Piotrowski W., 2003. Impact of plant extracts on vitality and root healthiness of leguminous plants inoculated by Fusarium oxysporum (Schl.) Rocz. Ochr. Roślin, 5: 191-202.

Schmitt S.D., Carralho S. M., Seddon B., Koch E., 2005. Evaluation of biocontrol preparations and plant extracts for the control of Phytophthora infestans on potato leaves. Eur. J. Pl. Pathology, 112 (3): 235-246.

Sefidkon F., Dabiri F.M., Mohammad N., 2004. Analysis of soil Heracleum persicum L. (seeds and stems). J. Essent. Oil Res. 16: 296-298.

Sehajpal A., Arora S., Kaur P., 2009. Evaluation of plant extracts against Rhizoctonia solani causing sheath blight of rice. J. Pl. Protec Sc. 1 (1): 25-30.

Shohong Z., Enping Z., Baoli Z., Yuvan Z., 2009. Allelopathic effects of Sophera flavescens ait. extracts on Verticillium dahliae. Allelopathy, J. 24 (1): 199-206.

Skirgiełło A., Zadara M., Ławrynowicz M., 1979. Grzyby (Mycota). 10. Glonowce (Phycomyce- tes). Pleśniakowe (Mucorales). PAN Instytut Botaniki, Warszawa-Kraków. (in Polish).

Slusarenko A.J., Patel A., Portz D., 2008. Control of plant diseases by natural products: Allicin from garlic as a case study. Eur. J. Pl. Pathology, 121: 313-322.

Srivastova A.K., Lal B., 1997. Studies on bio-fungicidal properties of leaf extracts of some plants. Ind. Phytopathol. 50: 408-411.

Vatchev T., Hadjidimitrov B., 2006. Application of fungicides to control crown and root rot disease complex of greenhouse-grown tomatoes. Rasteniev'Dni Nauki, 43 (4): 331-339.

Wolski., Gliński Z., Buczek K., Wolska A., 1996. Otrzymywanie i charakterystyka roślinnych ekstraktów furanokumarynowych o działaniu przeciwgrzybicznym. / Preparation and characteristic of furanocoumarin plant extracts of anti-fungal activity. Herba Pol. 42: 168-173. (in Polish)

\section{Grzyby kolonizujące korzenie oraz glebę spod uprawy pomidora (Lycopersicum esculentum Mill.) chronionego biologicznie}

\section{Streszczenie}

Pomidor odmiany Rumba Ożarowska uprawiano w szklarni UWM w Olsztynie. Zastosowano ochronę $\mathrm{w}$ postaci opryskiwania i podlewania na przemian (po dwa razy) 5\% wodnymi wyciągami z następujących gatunków roślin: Aloe vulgaris Lam., Achillea millefolium L., Mentha piperita L., Polygonum aviculare L., Equisetum arvense L., Juglans regia L. i Urtica dioica $\mathrm{L}$. W kombinacji kontrolnej rośliny traktowano destylowaną wodą. Po zbiorach owoców pobierano próby korzeni i gleby. Korzenie odkażano i wykładano na podłoże PDA. Hodowlę grzybów glebowych prowadzono na podłożu Martina. Wyrosłe gatunki grzybów identyfikowano mikroskopowo.

Patogeny licznie - ponad $60 \%$ udział wśród ogółu izolatów, zasiedlały korzenie pomidora. Wśród nich zidentyfikowano następujące gatunki: Colletotrichum coccodes, Fusarium concolor, F. oxysporum i $F$. poae. Udział patogenów w zbiorowisku grzybów glebowych był nieznaczny, natomiast dominowały tam grzyby drożdżopodobne $-75,4 \%$ udział. Zastosowane wyciągi wodne w stężeniu 5\% ograniczały liczebność grzybów, w tym patogenicznych, zasiedlających korzenie oraz glebę spod uprawy pomidora. Najbardziej skuteczna okazała się ochrona biologiczna z zastosowaniem wyciągu z $P$. aviculare, a najmniej z użyciem wyciągu z J. regia. Najliczniejszą populację antagonistów Paecilomyces roseum i rodzaju Trichoderma w obu omawianych środowiskach stwierdzono w kombinacji $\mathrm{z}$ traktowaniem wyciągiem $\mathrm{z}$ A. millefolium, M. piperita i $U$. dioica. 